Jilke, Sebastian \& Van de Walle, Steven (2012): Two track public services? Citizens’ voice behaviour towards liberalized services in the EU15, Public Management Review, DOI:10.1080/14719037.2012.664015

\title{
TWO TRACK PUBLIC SERVICES? CITIZENS’ VOICE BEHAVIOR TOWARDS LIBERALIZED SERVICES IN THE EU15
}

\author{
Sebastian Jilke \\ jilke@fsw.eur.nl
}

\author{
Steven Van de Walle \\ vandewalle@fsw.eur.nl
}

Department of Public Administration

Erasmus University Rotterdam

3000 DR Rotterdam

The Netherlands

\begin{abstract}
The authors would like to thank three anonymous reviewers, the late Alex Kouzmin, participants of the open panel 'Dilemmas in the public sector' of the IRSPM conference 2011 in Dublin, and participants and organizers of the EGPA PhD seminar 2011 in Bucharest for valuable comments. The research leading to these results has received funding from the European Community’s Seventh Framework Programme under grant agreement No. 266887 (Project COCOPS), Socio-economic Sciences and Humanities; and from grant ODV-10-01 'Two-track public services? A longitudinal empirical perspective on tensions between democratic equity and liberalization of public services’ within the programma 'Omstreden Democratie’ of the Netherlands Organization for Scientific Research.
\end{abstract}


TWO TRACK PUBLIC SERVICES?

CITIZENS' VOICE BEHAVIOR TOWARDS LIBERALIZED SERVICES IN THE

EU15

\begin{abstract}
Is there evidence for the emergence of 'two-track’ public services, where the wealthiest, bestinformed and most assertive customers get the best quality service? In this paper, we use public opinion data of citizen complaint behavior from 2000 and 2004 towards services of general interest in $15 \mathrm{EU}$ countries to provide a first examination of the 'two-track' public services hypothesis. The findings only partly support the expectation that socio-economic factors did have a negative impact over time on citizen complaints. While education did not have such an effect, age did. However, these results should be regarded as provisional for various reasons.
\end{abstract}

Keywords: Eurobarometer, liberalization, services of general interest, voice 


\section{LIBERALIZED SERVICES AND CITIZENS' VOICE}

Turning public service providers into corporations that employ private sector management techniques has been on the agenda of policy makers for some time (Clifton, Comín, DíazFuentes 2007). Following large-scale reforms, inspired by European integration and liberalization, the publicness of many so-called services of general interest ${ }^{\mathrm{i}}$, such as public utilities, public transport, postal services etc, changed (Héritier 2001, Van de Walle 2008). The purpose was to turn state monopolies into competitive private or semi-private providers. For citizens, this meant they became to be seen as vocal, empowered consumers of public services, rather than mere legal subjects. According to this model, citizens should be viewed as customers who make well-informed choices, with all rights and entitlements to consideration and service that this entailed (Aberbach, Christensen 2005, Clarke, Newman 2007).

Recent government initiatives in this regard have been increasingly focused on providing greater opportunities for citizen voice ${ }^{\mathrm{ii}}$. The introduction of more extensive voice mechanisms (along with the possibility of provider choice) aims at improving the responsiveness and subsequently the performance of public services by emphasizing the central role of the citizen in the process of service delivery (Le Grand 2007). They are also important constituents within the liberalization of services of general interest debate in European public sectors (Clifton, Díaz-Fuentes 2010, Clifton et al. 2005, Vael et al. 2008).

Many authors have discussed the anti-democratic implications of these kind of reforms (Behn 1998, Box et al.2001, Gottfried 2001), especially their propensity to establish a 'supermarket state' model, where the wealthiest, best-informed and most assertive customer get the best quality service (Olsen 1988, Christensen, Lægreid 2002). In line with this, the services of general interest reform has been severely criticized, as it is thought this shift has disadvantaged potentially vulnerable citizens (Clifton et al. 2011) and created a 'two-track' 
public service. This research note provides a very first empirical outlook on this assumption by analyzing Eurobarometer public opinion data on stated voice behavior (complaints) towards liberalized public services in 15 member countries of the European Union (EU) for the years 2000 and $2004^{\mathrm{iii}}$.

The shift from collective-oriented models to individualized customer-based models have been studied from a variety of academic disciplines, and often highlight the managerial imperatives at the heart of these reforms (Clarke, Newman 2007, Learmonth, Harding 2006). More recently, we have also seen increasing attention to studying public attitudes towards public services (Fiorio et al. 2007, James 2009, Van Ryzin 2006), and towards the effects of liberalization in certain sectors (Brau et al. 2010, Bacchiocchi, Florio and Gambaro 2011, Clifton et al. 2011, Fiorio, Florio 2011). Examples include studies looking at cohort changes in satisfaction with health care (Adang, Borm 2007) or studies looking at public preferences for or against public or private provision of public services (Wendt et al. 2010). In this research note, we want to build on these initial studies.

The structure of this research note is as follows: first we introduce our research question, so as data and methodology. Findings from our empirical analysis are presented consecutively where we assess whether an association can be found between citizens' voice behavior and their socio-economic status, and if we can establish a link towards the liberalization of services of general interest. Following, we discuss our results, limitations of the study and draw some conclusions for future research.

\section{RESEARCH QUESTION, DATA AND METHODODLGY}

We aim at assessing the relationship between citizens' socio-economic status and their stated complaint behavior towards liberalized services of general interest in $15 \mathrm{EU}$ member countries for the period between 2000 and 2004. Hence we test whether there are differences 
for different socio-economic groups in exercising voice towards any aspect of a received service. We are particular interested whether potential differences between contrasting layers of society increased (or decreased) over time, and if so, whether this process can be attributed to the liberalization of services of general interest. Furthermore, we assess our findings in the light of data and item availability and conclude with indications for the future research agenda in this field of study.

We estimate a binary logistic regression model using Eurobarometer data between 2000 and 2004. In general, Eurobarometer public opinion surveys are commissioned by the European Commission twice a year since 1973. They contain approximately 1,000 respondents in each country $^{\text {iv }}$. National samples are drawn using a multi-stage random probability sampling design from the total population aged 15 and above. The data is weighted in proportion to its share in the total population of the EU15 member countries, aged 15 and over. These adjustments are based on EUROSTAT population figures and include post-stratification sample weighting factors (GESIS 2008).

Between 1997 and 2008, six Eurobarometer rounds have been devoted to citizens' perceptions on (public) services (47.1 in 1997; 53.0 in 2000; 58.0 in 2002; 62.1 in 2004; 63.1 in 2005; 63.1 in 2006), plus two flash surveys ${ }^{\mathrm{v}}$ - one on service quality (flash 150) in 2003 and one on switching service providers (flash 243) in 2008. For our analysis, we merged the most relevant datasets (2000, 53.0 and 2004, 62.1). In total, they provide a sample of 31,429 respondents for all EU15 member countries - due to missing values, our sample dropped by $3 \%$ to 30,488 respondents.

\section{Dependent variable}

Within the analysis, we will focus on the impact of citizens' socio economic factors towards their stated voice behavior, using the following item: 
"In the last twelve months, have you personally made a complaint, either to any complaint-handling body (ombudsman, regulator, consumer association, industry body, etc...) or the service provider about any aspect of [...]?”.

As our dependent variable, we constructed a binary dichotomous variable (has complained about one of the services/ has not complained at all), incorporating the following liberalised services: electricity, gas, fixed phone, mobile phone, water, postal services, rail and local transport, by simply adding them up. We use this composite measure of voice in order to reduce effects of missing cases within certain service sectors ${ }^{\mathrm{vi}}$, as well as to increase the total number of complaints within our analysis. The advantage of this procedure is that it makes the analysis less sensitive and more robust. The other side of this rather pragmatic approach is that we aggregate experiences within specific service sectors. However, these sectors do have indeed different characteristics within and across single countries - we will further discuss this point in the discussion of results.

The 2000 (53.0) dataset is the first Eurobarometer round that contains information whether respondents have actually submitted a complaint. It has been incorporated in the same way repeatedly until 2004 (62.1). In 2006 (63.1) the question was asked in a more fragmented manner, as it was changed from a binary answer to four answer possibilities, probing for different kinds of institutions complaints could be submitted to. This affects comparability negatively, as it reduces the overall probability in selecting "no" as an answer by decreasing the share of the "no" category from 50\% to 25\%. Furthermore, in 2006 the time span was extended to 24 months. Another difference which was observed between the Eurobarometer rounds in 2000 and 2004, was that in 2004 the question on voice was asked exclusively to service users (those respondents that had stated that they actually use the service and have access to it), while in 2000 all respondents were included. In order to reduce the effect this procedure might have on the results obtained, we filtered those respondents in 2000 who had 
stated that they have no access to the respective service - figures on service use were not available at that time. This still may have a minor impact on the results obtained.

The cross-national reliability of the survey item has been tested by comparing item nonresponse seize and characteristics of sub-components of our dependent variable (specific service sectors) per country. Results reveal no significant differences across countries for those respondents opting for the “don't know” answer.

\section{Table 1: Descriptive Statistics}

Source: Eurobarometer 53.0, 2000; Eurobarometer 62.1, 2004

\begin{tabular}{lcccc}
\hline & Mean & SD & Min, Max & $N$ \\
\hline $\begin{array}{l}\text { Dependent variable } \\
\text { Voice }\end{array}$ & .17 & .377 & 0,1 & 30,570 \\
& & & & \\
$\quad \begin{array}{l}\text { Independent variables } \\
\text { Education }\end{array}$ & 1.98 & .757 & 1,3 & 31,120 \\
Age & 2.75 & 1.072 & 1,4 & 31,429 \\
& & & & \\
Control variables & - & - & 1,15 & 31,429 \\
$\quad$ Country & .49 & .500 & 0,1 & 31,429 \\
$\quad$ Year & 11.42 & 4.316 & 1,32 & 30,479 \\
$\quad$ Service quality & .48 & .500 & 0,1 & 31,429 \\
$\quad$ Gender & & & &
\end{tabular}




\section{Independent variables}

For our independent variables we utilize available socio-economic indicators as proxies for potential vulnerability (see also Clifton et al. 2011), namely the respondents' age and educational status - income was not included in the initial Eurobarometer database. We constructed four age groups: 15-24 years; 25-39 years; $40-54$ years; and 55 years and older. As regards educational status, we grouped respondents in accordance to their age when they left fulltime education into three categories: basic education ( $<15$ years), secondary education (16-19years) and higher education (>20 years). In order to minimize effects, respondents which were still studying were assigned to one of the three categories in correspondence to their age.

Additionally, we included two interaction terms (Aiken, West 1996) for Year (2000=0, 2004=1) * Education and Year * Age. By this, we aim at assessing whether there is an interaction between time and potential vulnerability when it comes to exercising voice. In other words, the first term measures whether educational attainment over time increases or decreases the probability of submitting a complaint. The second term assess whether the same holds true for age. Following this procedure, we want to find out how a potential equality gap in terms of exercising voice between different socio economic groups develops over time.

We seek to control for important factors that have an influence on citizens' voice behavior. First we control for country effects by constructing dummy variables with Ireland as reference, which has, in terms of voice, the closest mean to the grand mean. Furthermore, we controlled for perceived service quality of received services, where we constructed a composite measure by adding perceived service quality variables ${ }^{\mathrm{vii}}$ from all services included. On top we included the respondents' gender and the survey's year as additional control variables. The Eurobarometer dataset does not provide other potentially important control variables such as expectations towards service quality - we will take this issue into account in the discussion of the results. 


\section{PATTERNS OF CITIZENS’ VOICE BEHAVIOR IN THE EU15}

We first examined developments over time for the share of respondents that have actually submitted a complaint for all available service sectors in the EU15 (figure 1). Here an increase in complaints - indeed, in different degrees - was apparent in all service sectors. However, we can clearly identify differences across sectors. While there has been a rather strong increase in complaints in the telephony and rail sectors, the remaining sectors experienced only some minor changes of less then two percentage points between the years.

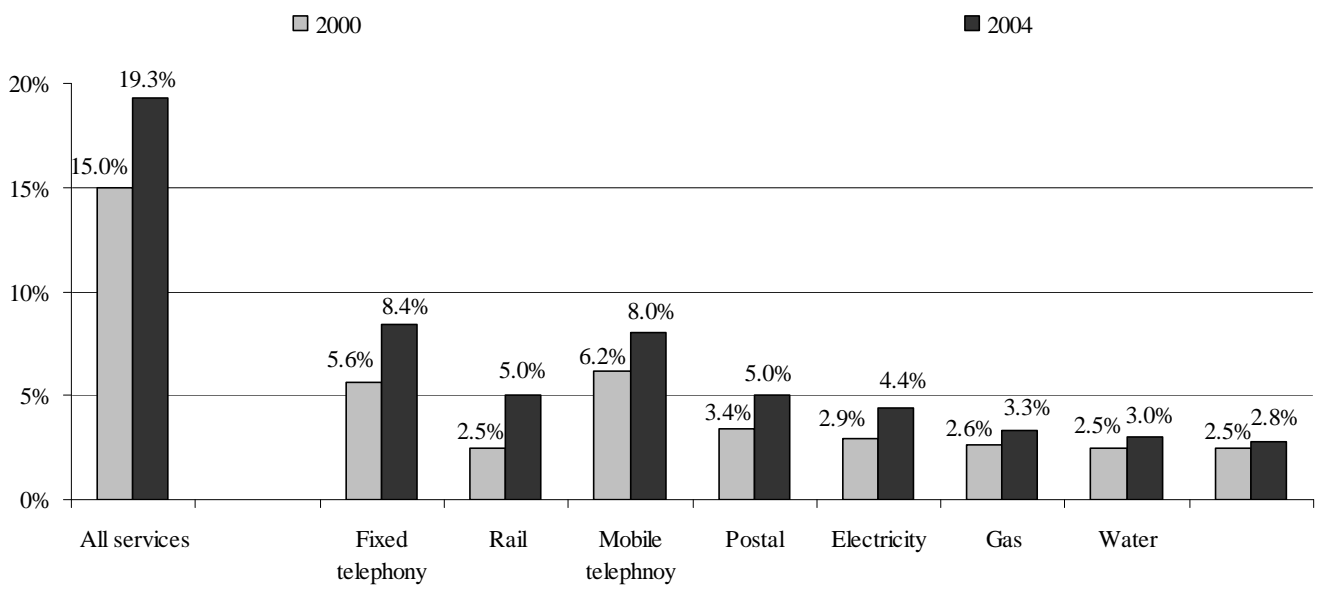

Figure 1: Complaints made in the last 12 months (EU15)

Source: Own calculations based on Eurobarometer 53.0, 2000; Eurobarometer 62.1, 2004.

In this regard, we estimate a binary logistic regression model (Hosmer, Lemeshow 2000) with voice behavior as dependent variable. In general, we observe a relatively low Pseudo $\mathrm{R}^{2}$ and Nagelkerke $\mathrm{R}^{2}$, showing that our model does not fully explain citizens' voice behavior, however, that was not our intention. Moreover, we do find a good model fit for our model. 
Table 2: Binary logistic regression for reported voice behavior

\begin{tabular}{|c|c|c|}
\hline \multicolumn{3}{|c|}{ EU 15} \\
\hline & $\boldsymbol{B}$ & $\operatorname{Exp}(B)$ \\
\hline \multicolumn{3}{|l|}{ Control variables } \\
\hline \multicolumn{3}{|l|}{ Country (Ref. Ireland) } \\
\hline France & -.856 & $.425 * * *$ \\
\hline Belgium & .036 & 1.037 \\
\hline The Netherlands & .125 & 1.133 \\
\hline Germany & -.116 & .891 \\
\hline Italy & -.278 & .757 \\
\hline Luxembourg & -.999 & .368 \\
\hline Denmark & .198 & .1219 \\
\hline Austria & .146 & 1.157 \\
\hline United Kingdom & .354 & $1.425^{*}$ \\
\hline Greece & -.206 & .814 \\
\hline Spain & -.145 & .865 \\
\hline Portugal & -.825 & $.438 * * *$ \\
\hline Finland & .375 & 1.455 \\
\hline Sweden & .797 & $2.218^{* * *}$ \\
\hline Year 2004 (Ref. 2000) & .287 & $1.332 * *$ \\
\hline Service Quality & .079 & $1.082 * * *$ \\
\hline Gender (Ref. male) & -.049 & .953 \\
\hline \multicolumn{3}{|l|}{ Independent variables } \\
\hline \multicolumn{3}{|l|}{ Education (Ref. high) } \\
\hline Education low & -.636 & $.529 * * *$ \\
\hline Education medium & -.279 & $.757 * * *$ \\
\hline \multicolumn{3}{|l|}{ Age (Ref. 55+ years) } \\
\hline $15-24$ years & .416 & $1.516^{* * *}$ \\
\hline 25-39 years & .393 & $1.481^{* * *}$ \\
\hline $40-54$ years & .412 & $1.509 * * *$ \\
\hline \multicolumn{3}{|l|}{ Interaction Terms } \\
\hline Year X Education low & .434 & $1.544^{* * *}$ \\
\hline Year X Education medium & .024 & 1.024 \\
\hline Year X 15-24 years & .106 & 1.112 \\
\hline Year X 25-39 years & .229 & $1.257^{*}$ \\
\hline Year X 40-54 years & -.081 & .022 \\
\hline Constant & -2.626 & $.072 * * *$ \\
\hline Nagelkerke $\mathrm{R}^{2}$ & \multicolumn{2}{|c|}{.084} \\
\hline Pseudo $\mathrm{R}^{2}$ & \multicolumn{2}{|c|}{.050} \\
\hline Correctly predicted & \multicolumn{2}{|c|}{$82.9 \%$} \\
\hline
\end{tabular}




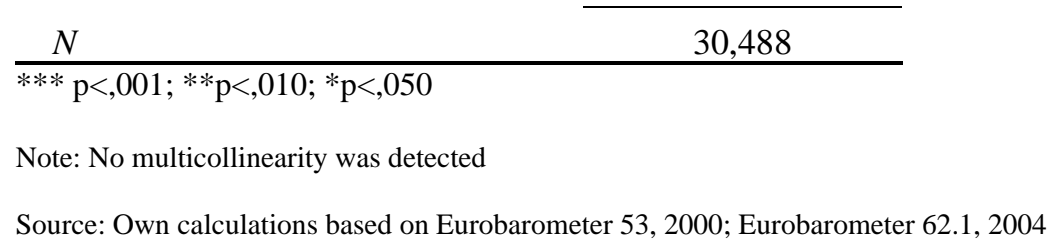

Findings reveal that country effects are apparent which suggests that there are considerable differences in exercising voice between countries. Most controls are statiscally significant and pointing in the expected direction. Service quality of the received service, so as developments over time, does play a statiscally significant role in this regard. The only control variable that had no effect on voice behavior was gender. Regarding our independent variables, both predictors, education and age, are statiscally significant. It shows that less educated respondents are less likely to submit a complaint when compared to those that exit the educational system at a later stage. The magnitude of the odds in this regard is stronger for low educated than for medium educated respondents. As regards age, we find middle aged respondents to be more likely to exercise voice when compared to those 55 years and older. Here again, we can find see some differences within the odds, showing that respondents between 25-39 years are the 'strongest' group, followed by those 40-54 years old.

The inclusion of interaction terms did improve the explanatory power of the statistical model and had no significant effect on our independent variables. Here we can see that education had a positive effect on our dependent variable over time, which may also imply that low educated people have complained more frequently in 2004 than in 2000. This is contrary to our expectation that education decreases the odds of complaining over time. As for age, we find that those respondents 25-39 years old are complaining more often over the years when compared to those 55 years and older. In other words, this point in the direction that the effect of education and age on exercising voice, namely that less educated and elderly are less likely to do so is differing. While being low educated seems not to decrease the probability of 
exercising voice over time, being 55 years and older did. However, the observed effect for age is rather small.

Our findings only partly support our expectation that socio-economic factors did have a negative impact over time on voice behavior towards liberalized services. While education has not such an effect on citizen complaint behavior, age has. Hence our data suggest that the gap in submitting complaints between the young and vital, and the elderly increases over time. As regards educational status, that opposite seems to hold true, meaning that the gap between different educational groups decreases over time. However, these results should be regarded as provisional for various reasons, on which will elaborate in the following.

\section{DISCUSSION AND FUTURE RESEARCH}

So far our findings do indicate an equality gap between different layers of society when exercising their voice by submitting a complaint. More precisely, results suggest that lower educated citizens are less likely to submit a complaint when compared to those with a higher education. Age has a considerably weaker effect on the likelihood of complaining. These findings are in line with previous research (Dowding, John 2008, Thomas, Melkers 1999, Thomas 1982). Furthermore, we provide first support for the assumption that the gap between the young and the elderly does increase over time. Education, against our expectations, did not have a similar effect. In contrary, being low educated increases the likelihood of submitting a complaint between 2000 and 2004, which suggest that the gap between different educational groups is decreasing. In this regard, we have to keep in mind that these are only overall tendencies that do not necessarily reflect sectoral developments which might vary accordingly.

Our analysis may suffer from a number of potentially biases that need to be discussed. First we had to aggregate voice behavior for specific service sectors to a single item in order to produce reliable results. On the one side this procedure solves a methodological issue, but on 
the other it raised a new problem. Reforms within different countries and different service sectors are diverse in terms of reform depth and speed (Conway, Nicoletti 2006). Therefore, our composite measure of voice is not able to trace developments within specific sectors, but it may provide a first overall direction (see also Ferrari, Pagani and Fiorio 2010 for a comparable approach using a composite measure across four different sectors for satisfaction with services of general interest) for more in depth research in the future. Second, attributing our findings to the process of service liberalization proves to be difficult for two reasons: we did provide no real ex-ante/ ex-post comparison of reforms, and our timeline of four years is rather short; different degrees of liberalization within different sectors can not be adequately attributed to our aggregated measure of citizens’ voice.

In this light we can not be fully confident that our findings stay unchanged when adding additional controls (such as expectations), or assessing developments in single service sectors. Hence, our findings provide only a tendency in this regard. This exemplifies the fact that citizen complaint behavior in the light of service liberalization proves to be a complex issue that needs to be assessed at a more disaggregated level. In this regard, we regard our results as a first stepping stone in contributing to a wider puzzle: the effects of service liberalization reforms on citizens' attitudes and behaviors in European public sectors.

Further research efforts in this strand of study need to take various factors into account. As we have shown, citizen complaint behavior might be affected by socio economic factors, but also may be a result of expectations (which might vary for different sub-groups). In this regard, age and education are certainly of importance, but there are maybe other socio-economic variables that also influence ones' complaint behavior, such as wealth, or social-class, or even more general (and perhaps underlying) sets of values. In the future, those set of variables need to be taken into the equation when estimating voice behavior. Furthermore, relying on secondary data we estimated our model for stated and not observed complaints. Future work 
may also make use of data on observed complaint behavior in order to capture actual rather than just reported behavior.

Moreover, we need to expand our focus by looking not only at short time spans, so as individual factors but also at institutional factors such as different regulatory regimes within a longer period of time. Hence we are in need for further research on the impact of service liberalization on voice behavior taking long-term developments or ex-post/ ex-ante comparisons of liberalization reforms within countries and specific service sectors into account, ideally using a longitudinal multilevel modelling strategy. Therefore, future investigations may use additional data sources since Eurobarometer is limited in terms of comparison over time, and changes of the wording within the Eurobarometer questionnaire do not permit comparisons beyond 2004. In the case that such data is not available, a sole multilevel model, focusing on the regulatory status of specific service sectors, would also produce potentially interesting findings.

\footnotetext{
${ }^{\mathrm{i}}$ For the sake of clarity we do summarize service of general economic interest as well as service of general interest under this term. Their legalistic distinction has been extensively discussed elsewhere (Prosser 2005).

ii In this research note we focus on the formalized individual element of voice within the service delivery cycle, what Dowding et al. (2000) call individual voice, namely complaining about any aspect of used services.

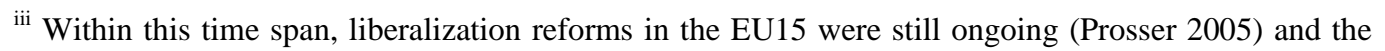
overall regulatory status (measured through the OECD’s ETCR indicators) between 2000 and 2004 for all those countries differs significantly (Conway, Nicoletti 2006).

${ }^{\text {iv }}$ With the exception of Germany (2,000 respondents), Luxembourg (600 respondents) and the UK (1400 respondents).
} 
${ }^{\vee}$ While standard and special EB rounds are conducted through face-to-face interviews, flash surveys collect information by telephone interviews.

vi The amount of missing data and non-users within single service sectors compromises almost $10 \%$ and above.

vii The item was phrased as follows: “Overall, what do you think of the quality of [...] that you use? Would you say it is very good, fairly good, fairly bad, or very bad?”. It has been incorpatated for all service sectors used within this study. We have then simply summed-up all answers to a single variable, which we have labeled "service quality” (see also table 1). 


\section{REFERENCES}

Aberbach, J.D. and Christensen, T. (2005) "Citizens and consumers ", Public Management Review 7:2 pp 225-46.

Adang, E.M.M. and Borm, G.F. (2007) "Is there an association between economic performance and public satisfaction in health care?", The European Journal of Health Economics 8:3 pp 279-85.

Aiken, L.S. and West, S.G. (1996) Multiple Regression: Testing and Interpreting Interactions, London: Sage Publications.

Bacchiocchi, E., Florio, M. and Gambaro, M. (2011) “Telecom reforms in the EU: prices and consumers’ satisfaction” Telecommunications Policy 35:4 pp. 382-96.

Behn, R.D. (1998) "The new public management paradigm and the search for democratic accountability", International Public Management Journal 1:2 pp 131-64.

Box, R.C., Marshall, G.S., Reed, B.J. and Reed, C.M. (2001) "New public management and substantive democracy", Public Administration Review 61:5 pp 608-19.

Brau, R., Doronzo, R., Fiorio, C.V. and Florio, M., (2010), "EU gas industry reforms and consumers' prices”, The Energy Journal 31: 4 pp. 163-78.

Christensen, T. and Lægreid, P. (2002) "New public management: Puzzles of democracy and the influence of citizens", Journal of Political Philosophy 10:3 pp 267-95.

Clarke, J. and Newman, J. (2007) "What's in a name? New labour's citizen-consumer and the remaking of public services", Cultural Studies 21:4-5 pp 738-57.

Clarke, J., Newman, J., Smith, N., Vidler, E. and Westmarland, L. (2007) Creating citizenconsumers: changing publics and changing public services, London: Sage Publications.

Clifton, J., Comín, F. and Díaz-Fuentes, D. eds. (2007) Transforming public enterprise in Europe and North America, Houndmills: Palgrave.

Clifton, J., Díaz-Fuentes, D., Fernandez-Gutiérrez, M. and Revuelta, J. (2011) "The brave new world of public infrastructure: Is market-oriented reform producing a 'two-track' Europe?" COCOPS Working Paper No.2, Rotterdam.

Clifton, J. and Díaz-Fuentes, D. (2010) "Evaluating EU Policies on Public Services: A Citizens' Perspective" Annals of Public and Cooperative Economics 81:2 pp 281-311.

Clifton, J., Comín, F. and Díaz-Fuentes, D. (2005) "Empowering Europe's Citizens? Towards a Charter for Services of General Interest" Public Management Review 7:3 pp 417-43.

Conway, P., Nicoletti, G. (2006). "Product Market Regulation in the Non-Manufacturing Sectors of OECD Countries: Measurement and Highlights" Economics Department Working Papers No.530, Paris: OECD. 
Dowding, K. and John, P. (2008) "The three exit, three voice and loyalty framework: a test with survey data on local services", Political Studies 56:2 pp 288-311.

Dowding, K., John, P., Mergoupis, T. and Van Vugt, M. (2000) "Exit, voice and loyalty: Analytic and empirical developments", European Journal of Political Research 37:4 pp 469-95.

Ferrari, A.F., Pagani, L. and Fiorio, C.V. (2010) "A Two-Step Approach to Analyze Satisfaction Data", Social Indicators Research, online first.

Fiorio, C.V. and Florio, M. (2011) "«Would you say that the price you pay for electricity is fair?» Consumers' satisfaction and utility reforms in the EU15”, Energy Economics 33, pp.178-87.

Fiorio, C.V., Florio, M., Salini, S. and Ferrari, P. (2007) "European consumers attitudes on services of general interest: accessibility, price and quality", Marrelli, M., Padovano, F. and Rizzo, I. (eds.) Servizi Pubblici: Nuove Tendenze nella Regolamentazione, nella Produzione e nel Finanziamento, Milano: Franco Angeli.

GESIS (2008) Weighting overview. Available: http://www.gesis.org/eurobarometer/surveyseries/standard-special-eb/weighting-overview/ [1 June 2011].

Gottfried, P.E. (2001) After liberalism: mass democracy in the managerial state, Princeton: Princeton University Press.

Héritier, A. (2001) "Market integration and social cohesion: the politics of public services in European regulation", Journal of European Public Policy 8:5 pp 825-52.

Hosmer, D.W. and Lemeshow, S. (2000) Applied logistic regression, New Jersey: WileyInterscience.

James, O. (2009) "Evaluating the Expectations Disconfirmation and Expectations Anchoring Approaches to Citizen Satisfaction with Local Public Services", Journal of Public Administration Research and Theory 19:1 pp 107-23.

Le Grand, J. (2007) The other invisible hand: delivering public services through choice and competition, Princeton: Princeton University Press.

Learmonth, M. and Harding, N. (2006) "Evidence-based management: the very idea", Public Administration 84:2 pp 245-66.

Olsen, J.P. (1988) "Administrative reform and theories of organization" in B.G. Peters and C. Campbel eds., Organizing governance: Governing organizations, Pittsburgh: University of Pittsburgh Press, pp 233-54.

Poister, T. and Thomas, J.C. (2011) "The Effect of Expectations and Expectancy Confirmation/Disconfirmation on Motorists' Satisfaction with State Highways", Journal of Public Administration Research and Theory, 21:4 pp 601-17.

Prosser, T. (2005) The limits of competition law: markets and public services, Oxford: Oxford University Press. 
Thomas, J.C. (1982) "Citizen-Initiated Contacts with Government agencies: A Test of Three Theories", American Journal of Political Science, 26 pp 504-22.

Thomas, J.C. and Melkers, J. (1999) "Explaining Citizen-Initiated Contacts with Municipal Bureaucrats", Urban Affairs Review, 34:5 pp 667-90.

Vael, T., Vandekerckhove, S., Van Gyes, G., Van Roosbroek, S., Verhoest, K. and Coppin, L. (2008) Liberalisation in services of general economic interest: A bottom up citizens' perspective. Analysis of the PIQUE survey. Leuven: Higher Institute of Labour Studies.

Van de Walle, S. (2008) "What services are public? What aspects of performance are to be ranked? The case of "services of general interest"", International Public Management Journal, 11:3 pp 256-74.

Van de Walle, S. (2006) "The impact of public service values on services of general interest reform debates", Public Management Review 8:2 pp 183-205.

Van Ryzin, G.G. (2006) "Testing the expectancy disconfirmation model of citizen satisfaction with local government", Journal of Public Administration Research and Theory,16:4 pp 599-611.

Wendt, C., Kohl, J., Mischke, M. and Pfeifer, M. (2010) "How do Europeans perceive their healthcare system? Patterns of satisfaction and preference for state involvement in the field of healthcare", European Sociological Review 26:2 pp 177-92. 